patients ( 5 infliximab and certolizumab each, 2 adalimumab and 2 tociluzumab). Remission was observed in $84 \%$ of the patients. At least one relapse was occured in $43 \%$ and $>1$ relapse in $\% 14$ patients. At the last visit $26 \%$ were determined to have an active disease. $A>4 \mathrm{mg}$ of methylprednisolone dose was required in only $8.4 \%$. Mortality rate was $3.7 \%$ (4 patients).

Table 1 Clinical characteristics and outcomes of patients

\begin{tabular}{|c|c|}
\hline Gender $(F)$ & $96(89,8 \%)$ \\
\hline $\begin{array}{l}\text { Takayasu Arteritis Type } \\
1 \\
2 \\
3 \\
4 \\
5 \\
\end{array}$ & $\begin{array}{l}42(38,8 \%) \\
8(7,4 \%) \\
0(0 \%) \\
2(1,8 \%) \\
55(51,8 \%)\end{array}$ \\
\hline $\begin{array}{l}\text { Age at symptom onset } \\
\end{array}$ & $\frac{30(1,06)}{30(14-67)}$ \\
\hline $\begin{array}{l}\text { Age at diagnosis } \\
\end{array}$ & $33(14-68)$ \\
\hline Tme for diagnosis delay (months) & $12(0-180)$ \\
\hline Follow-up time (months) & $72(6-264)$ \\
\hline $\begin{array}{l}\text { Cardiovascular risk factors (Baseline, } \\
\text { Hamenton }\end{array}$ & \\
\hline Hypertension & $\begin{array}{l}41(\% 38,3) \\
6(\% 5,0)\end{array}$ \\
\hline $\begin{array}{l}\text { Diaberes } \\
\text { Dislipidemia }\end{array}$ & $25(\% 23,4)$ \\
\hline Coronary artery disease & $13(\% 12,1)$ \\
\hline Congestive heart falure & $4(3,7 \%)$ \\
\hline $\begin{array}{l}\text { peripheral artery disease } \\
\text { Stroke }\end{array}$ & $\begin{array}{l}13(12,1 \%) \\
10(9,3 \%)\end{array}$ \\
\hline Smoking & \\
\hline Current & $30(28 \%)$ \\
\hline $\begin{array}{l}\text { Former } \\
\text { Family history of atherosclerosis }\end{array}$ & $\begin{array}{l}6(5,6 \%) \\
28(26,2 \%)\end{array}$ \\
\hline Laboratory findings (baselime) & \\
\hline $\begin{array}{l}\mathrm{ESR}(\operatorname{mm} \mathrm{h}) \\
\mathrm{CRP}(m \mathrm{~L})\end{array}$ & $\begin{array}{l}43.8 \div 27.9 \\
18.2 \pm 22.6\end{array}$ \\
\hline Treatment at last visit n (\%) & \\
\hline Immunsupressives & $100(93.4 \%)$ \\
\hline Methotrexate & $16(15 \%)$ \\
\hline $\begin{array}{l}\text { Azathiopurin } \\
\text { Leflumomide }\end{array}$ & $\begin{array}{l}49(45.8) \\
20(18.7 \%)\end{array}$ \\
\hline $\begin{array}{l}\text { Letlinomide } \\
\text { Infliximab }\end{array}$ & $\begin{array}{l}20(1.9 \%) \\
2(1.9 \%)\end{array}$ \\
\hline Adalimumab & $1(0.9 \%)$ \\
\hline $\begin{array}{l}\text { Certolizumab } \\
\text { Tocilizumab }\end{array}$ & $3(2.8 \%)$ \\
\hline Certolizumab+Azathioprine & $1(0.9 \%)$ \\
\hline Certolizumab+methotrexate & $1(0.9 \%)$ \\
\hline Infliximab + azathioprime & $3(2.8 \%)$ \\
\hline Adalimumab+ Leflunamide & $1(0.9 \%)$ \\
\hline Glucocorticoids* & $51(47.7 \%)$ \\
\hline $\begin{array}{l}\leq 4 \mathrm{mg} \\
>4 \mathrm{mg}\end{array}$ & $42(39.2 \%)$ \\
\hline $\begin{array}{l}>4 \mathrm{mg} \\
\text { Cumulative glucocorticoid dose (g) }\end{array}$ & \begin{tabular}{|l|}
$\frac{9(8.4 \%)}{}$ \\
$7.5(0-31.9)$
\end{tabular} \\
\hline & \\
\hline $\begin{array}{l}\mathrm{VDI}^{* *} \\
\text { TADS*** }\end{array}$ & $\begin{array}{l}5.6 \pm 2.3 \\
8.2 \pm 3.1\end{array}$ \\
\hline
\end{tabular}

Conclusions: We have defined the long-term follow-up results of our Takayasu's arteritis cohort. Comparing with European and Asia series published recently, requirement for a surgical intervention was lower under immunosuppressive treatments in our series. However, disease activity and relapse rate were still high under conventional ISs, suggesting a need for better therapeutic options.

Disclosure of Interest: None declared

DOI: 10.1136/annrheumdis-2018-eular.4790

\section{THU0463 COMPLEMENT FACTORS OF THE ALTERNATIVE PATHWAY IN GPA AND MPA}

S. Fukui ${ }^{1}$, K. Ichinose ${ }^{1}$, K.-E. Sada ${ }^{2}$, M. Harigai $^{3}$, A. Kawakami ${ }^{1}$, on behalf of Japan Research Committee of the Ministry of Health, Labour, and Welfare for Intractable Vasculitis (JPVAS). ${ }^{1}$ Immunology and Rheumatology, Nagasaki University Graduate School of Biomedical Sciences, Nagasaki; ${ }^{2}$ Department of Nephrology, Rheumatology, Endocrinology and Metabolism, Okayama University Graduate School of Medicine, Dentistry and Pharmaceutical Sciences, Okayama; ${ }^{3}$ Department of Epidemiology and Pharmacoepidemiology, Tokyo Women's Medical University, Tokyo, Japan

Background: In antineutrophil cytoplasm autoantibody (ANCA)-associated vasculitis (AAV), involvement of complements, especially alternative pathway of complement, has been reported in researches using mouse models. In human, while some studies have identified levels of $\mathrm{C} 3$ as a renal prognostic factor, entire complement factors in alternative pathway have not been evaluated.

Objectives: To evaluate complement profiles of AAV patients at diagnosis and at 6 months after treatments (Month 6).

Methods: In total, 91 incident cases of granulomatosis with polyangiitis (GPA) and microscopic polyangiitis (MPA) based on the European Medicines Agency algorithm were enrolled. They are a part of participants of the Japanese nationwide, prospective, inception cohort study from 22 tertiary Japanese institutions (RemIT-JAV-RPGN). Multiplex complement bead assays to measure levels of C1q, C2, C3, C3b/iC3b, C4, C4b, C5, C5a, C9, Factor D, Factor I, MBL, factor B, factor $\mathrm{H}$, and properdin were performed using preserved sera at diagnosis and at Month 6. We compared complement levels at diagnosis of AAV patients with those of age- and sex-matched healthy donors, and compared those of the AAV patients at diagnosis and Month 6 .

Results: Seventy-two of 91 patients had serum both at baseline and Month 6 . Compared with healthy donors, GPA patients had significantly higher levels of $\mathrm{C} 2$, $\mathrm{C} 5 \mathrm{a}$, and Factor $\mathrm{B}$, and significantly lower levels of $\mathrm{C} 3 \mathrm{~b} / \mathrm{iC} 3 \mathrm{~b}, \mathrm{C} 4 \mathrm{~b}$, and properdin. MPA patients had significantly higher levels of $\mathrm{C} 2$ and Factor $\mathrm{D}$, and significantly lower levels of $\mathrm{C} 3 \mathrm{~b} / \mathrm{iC} 3 \mathrm{~b}, \mathrm{C} 4, \mathrm{C} 5$, Factor $\mathrm{H}$, and properdin (table 1). At baseline, GPA had significantly higher levels of $\mathrm{C} 4$, Factor $\mathrm{B}$ and Factor $\mathrm{H}$, and had significantly lower levels of $\mathrm{C} 4 \mathrm{~b}$ and Factor $\mathrm{D}$ compared to MPA. There are no significant differences in levels of $\mathrm{C} 3, \mathrm{C} 5$, Factor $\mathrm{D}, \mathrm{MBL}$, and properdin using Wilcoxon signed-rank test between at diagnosis and Month 6 both in GPA and MPA. Factor I significantly decreased at Month 6 only in GPA. Other complement factors significantly decreased at Month 6 both in GPA and MPA.

Abstract THU0463 - Table 1. Complement profiles of patients with AAV at baseline and healthy donors

\begin{tabular}{|c|c|c|c|c|c|c|}
\hline & $\begin{array}{c}\text { GPA } \\
\text { (median) }\end{array}$ & $\begin{array}{c}\text { MPA } \\
\text { (median) }\end{array}$ & $\begin{array}{c}\mathrm{HD} \\
\text { (median) }\end{array}$ & $\begin{array}{l}\text { GPA vs. } \\
\text { MPA }\end{array}$ & $\begin{array}{c}\text { GPA vs. } \\
\text { HD }\end{array}$ & $\begin{array}{c}\text { MPA vs. } \\
\text { HD }\end{array}$ \\
\hline $\mathrm{C} 1 \mathrm{q}, \mathrm{ng} / \mathrm{mL}$ & 104220 & 96890 & 108242 & N.S. & N.S. & N.S. \\
\hline $\mathrm{C} 2, \mathrm{ng} / \mathrm{mL}$ & 50181 & 54422 & 18610 & N.S. & $p<0.05$ & $p<0.05$ \\
\hline $\mathrm{C} 3, \mathrm{ng} / \mathrm{mL}$ & 1265500 & 1371550 & 1416900 & N.S. & N.S. & N.S. \\
\hline $\begin{array}{l}\text { C3b/iC3b, ng/ } \\
\mathrm{mL}\end{array}$ & 10433000 & 11066000 & 17364500 & N.S. & $p<0.05$ & $p<0.05$ \\
\hline C4, pg/mL & 310020 & 266554 & 308085 & $p<0.05$ & N.S. & $p<0.05$ \\
\hline $\mathrm{C} 4 \mathrm{~b}, \mathrm{ng} / \mathrm{mL}$ & 18064 & 27740 & 31287 & $p<0.05$ & $p<0.05$ & N.S. \\
\hline $\mathrm{C} 5, \mathrm{ng} / \mathrm{mL}$ & 30014 & 27805 & 32015 & N.S. & N.S. & $\mathrm{p}<0.05$ \\
\hline C5a, $\mathrm{pg} / \mathrm{mL}$ & 7783 & 6592 & 4836 & N.S. & $p<0.05$ & N.S. \\
\hline $\mathrm{C9}, \mathrm{ng} / \mathrm{mL}$ & 6934 & 5905 & 6742 & N.S. & N.S. & N.S. \\
\hline $\begin{array}{l}\text { Factor D, ng/ } \\
\mathrm{mL}\end{array}$ & 5335 & 7706 & 5658 & $p<0.05$ & N.S. & $p<0.05$ \\
\hline $\begin{array}{l}\text { Factor I, ng/ } \\
\mathrm{mL}\end{array}$ & 29917 & 25633 & 25653 & N.S. & N.S. & N.S. \\
\hline $\mathrm{MBL}, \mathrm{ng} / \mathrm{mL}$ & 3583 & 3638 & 3023 & N.S. & N.S. & N.S. \\
\hline $\begin{array}{l}\text { Factor B, ng/ } \\
\mathrm{mL}\end{array}$ & 254961 & 180045 & 212153 & $p<0.05$ & $p<0.05$ & N.S. \\
\hline $\begin{array}{l}\text { Factor } \mathrm{H}, \mathrm{ng} / \\
\mathrm{mL}\end{array}$ & 258187 & 228238 & 295480 & $p<0.05$ & N.S. & $p<0.05$ \\
\hline $\begin{array}{l}\text { Properdin, } \\
\mathrm{ng} / \mathrm{mL}\end{array}$ & 18794 & 19665 & 32521 & N.S. & $p<0.05$ & $\mathrm{p}<0.05$ \\
\hline
\end{tabular}

GPA, granulomatosis with polyangiitis; MPA, microscopic polyangiitis; HD, health donor.

Conclusions: We found some differences in complement factors among GPA MPA, and healthy donors. There were no differences of levels of C3, C5, Facto $D$, and properdin, which suggested involvements of alternative pathway, both in GPA and MPA between at diagnosis and Month 6 .

Disclosure of Interest: None declared

DOI: 10.1136/annrheumdis-2018-eular.3384

\section{THU0464 \\ INCREASED FREQUENCY OF OBSTRUCTIVE SLEEP APNEA SYNDROME IN BEHCET'S SYNDROME PATIENTS WITH VENA CAVA SUPERIOR THROMBOSIS}

A. Gokturk ${ }^{1}$, S.N. Esatoglu ${ }^{1}$, Y. Ozguler ${ }^{1}$, E. Atahan ${ }^{2}$, B. Musellim², V. Hamuryudan ${ }^{1}$, H. Yazici ${ }^{1}$, E. Seyahi ${ }^{1} .{ }^{1}$ Istanbul University, Cerrahpasa Medical School, Department of Internal Medicine, Division of Rheumatology, ${ }^{2}$ Istanbul University, Cerrahpasa Medical School, Department of Chest Diseases, Istanbul, Turkey

Background: Superior vena cava syndrome (SVCS), is a medical emergency and can also be seen in Behçet's syndrome (BS). Contrary to the severe outcome seen in malign conditions, SVCS in BS usually has a benign course, complicated rarely by hemoptysis, pleural effusion, and a chylothorax. We had noted that BS patients with SVCS frequently complained of sleep disturbances, snoring and sleep apnea, suggesting an obstructive sleep apnea (OSA) disorder.

Objectives: We formally surveyed the degree of risk for OSA among BS patients with SVCS and suitable controls using the Berlin questionnaire, a screening ques tionnaire for OSA with a high sensitivity and modest specificity. ${ }^{1}$

Methods: Because of the lower frequency of female patients with VCSS $(n=2)$ only males were included. We studied 28 BS patients with SVCS (Group 1), 80 BS patients with vascular involvement without a SVCS (Group 2), and 59 BS patients with no vascular involvement (Group 3). Also, 80 apparently healthy individuals (Group 4) of similar age and gender to BS patients were studied. Polysomnography was performed in patients at high risk for OSA according to the Berlin questionnaire.

Results: There were no differences regarding demographic characteristics, disease duration, and variables associated with OSA among the groups (table 1). The Berlin questionnaire categorised $57.1 \%(16 / 28)$ of the BS patients with SVCS (Group 1) as having a high risk for OSA and this was significantly higher compared to that found in the control groups. The frequency of those at high risk for OSA was $15 \%, 8.5 \%, 11.3 \%$ in Group 2,3 and 4 , respectively $(p>0.05)$. Until now, polysomnography was performed in 12 subjects ( 5 patients with SVCS, 1 patient with vascular involvement without a SVCS and 6 healthy controls). OSA was detected 